慶應義塾大学学術情報リポジトリ

Keio Associated Repository of Academic resouces

\begin{tabular}{|c|l|}
\hline Title & $\begin{array}{l}\text { Determination of air luminescence spectra for alpha-emitters with liquid scintillation } \\
\text { spectrometers }\end{array}$ \\
\hline Sub Title & \\
\hline Author & $\begin{array}{l}\text { 村瀬, 裕子(Murase, Yuko) } \\
\text { 本間, 義夫(Honma, Yoshio) } \\
\text { 滝上, 誠(Takiue, Makoto) } \\
\text { 油井, 多丸(Aburai, Tamaru) }\end{array}$ \\
\hline Publisher & 共立薬科大学 \\
\hline Publication year & 1988 \\
\hline Jtitle & $\begin{array}{l}\text { 共立薬科大学研究年報 (The annual report of the Kyoritsu College of } \\
\text { Pharmacy). No.33 (1988. ),p.173-173 }\end{array}$ \\
\hline JaLC DOI & \\
\hline Abstract & \\
\hline Notes & 抄録 \\
\hline Genre & Technical Report \\
\hline URL & https://koara.lib.keio.ac.jp/xoonips/modules/xoonips/detail.php?koara_id=AN00062898-0000003 \\
3-0173
\end{tabular}

慶應義塾大学学術情報リポジトリ(KOARA)に掲載されているコンテンツの著作権は、それぞれの著作者、学会または出版社/発行者に帰属し、その権利は著作権法によって 保護されています。引用にあたっては、著作権法を遵守してご利用ください。

The copyrights of content available on the KeiO Associated Repository of Academic resources (KOARA) belong to the respective authors, academic societies, or publishers/issuers, and these rights are protected by the Japanese Copyright Act. When quoting the content, please follow the Japanese copyright act. 


\title{
Determination of Air Luminescence Spectra for Alpha-Emitters with Liquid Scintillation Spectrometers
}

\author{
Yuko Murase, Yoshio Homma, Makoto Takiue**, and Tamaru Aburai*** \\ 村瀬裕子，本間義夫，滝上 誠**，油井多丸***
}

\begin{abstract}
Air luminescence spectra have been measured for ${ }^{210} \mathrm{Po},{ }^{238} \mathrm{U}$ and ${ }^{241} \mathrm{Am}$ with two commercially available liquid scintillation spectrometers. Since the measured endpoint of the air luminescence spectra is approx. $18 \mathrm{keV}$, they can be determined by liquid scintillation counting in the ${ }^{3} \mathrm{H}$ detection region. The average counting efficiencies measured with both counting systems were found to be $33.3 \%$ and $33.7 \%$, respectively. The air luminescence effect on liquid scintillation counting of gaseous $\alpha$-emitters is mentioned.
\end{abstract}

* 本報告は Appl. Radiat. Isot. (in press)

** 慈恵会医科大学

*** 日本原子力研究所ラジオアイソトープ・原子炬研修所. 